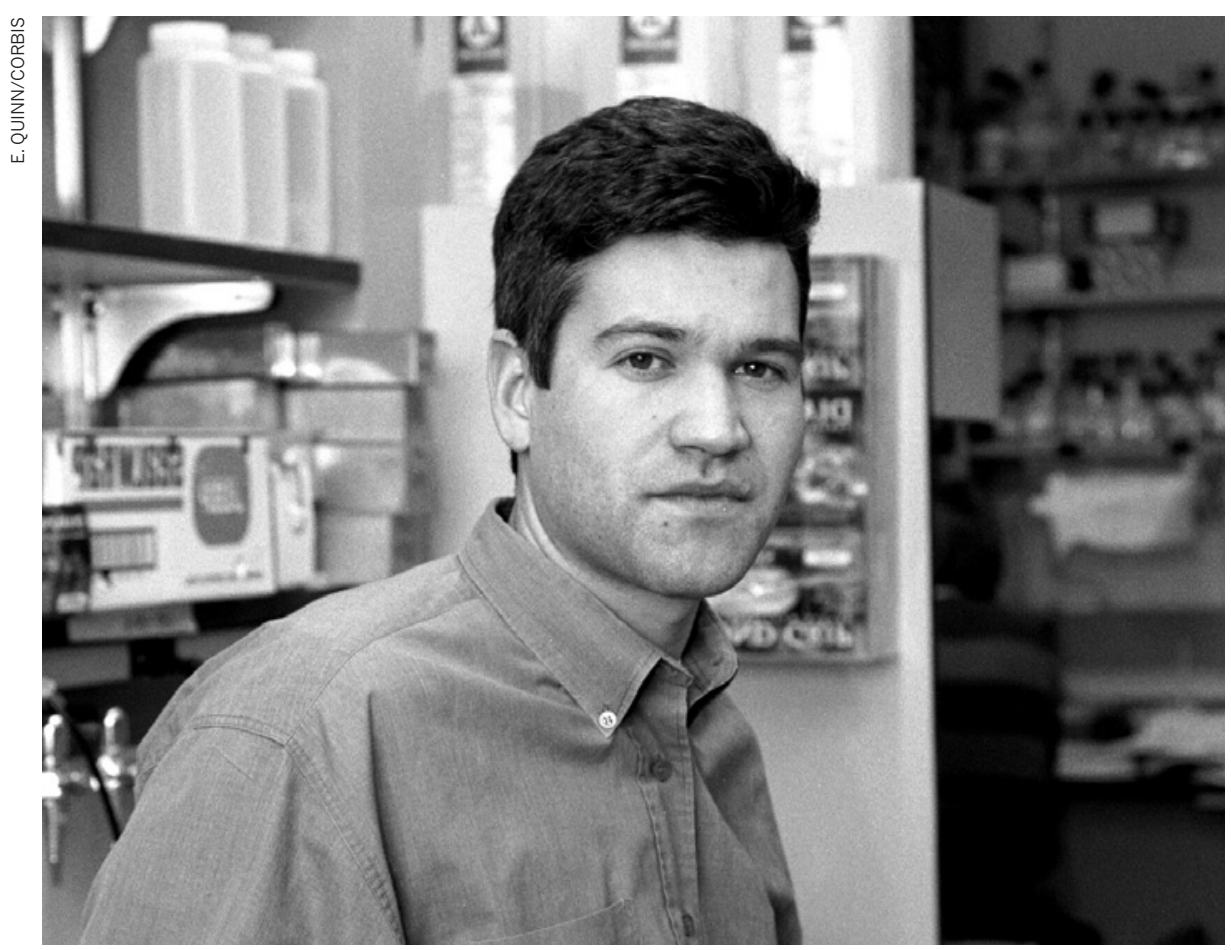

Luk Van Parijs fabricated data to obtain research funding from the US National Institutes of Health.

\title{
MISCONDUCT
}

\section{Biologist spared jail for grant fraud}

\section{A prompt confession and apparent remorse helped a former MIT researcher to secure a lighter sentence.}

\section{BY EUGENIE SAMUEL REICH}

A $\mathrm{n}$ immunologist who pleaded guilty to grant fraud in court has avoided jail after several prominent scientists wrote letters begging for clemency on his behalf. His sentence of home detention, community service and financial restitution, finalized on 15 June, suggests that coming clean promptly can be a good strategy for those who have committed scientific misconduct.

Luk Van Parijs was first confronted with evidence of data falsification by members of his laboratory in 2004, when he was an associate professor of biology at the Massachusetts Institute of Technology (MIT) in Cambridge. Within two days, he had confessed to several acts of fabrication and agreed to cooperate with MIT's investigation. MIT fired him after a yearlong inquiry, but he faced additional investigations by two other institutions - Harvard Medical School in Boston, Massachusetts, where he had been a graduate student, and the

California Institute of Technology in Pasadena, where he had been a postdoc - as well as by the US government's Office of Research Integrity.

The investigation reports, obtained by Nature under the US Freedom of Information Act, show that Van Parijs was found to be solely responsible for more than 11 incidents of data fabrication in grant applications and papers submitted between 1997 and 2004. Many described efforts to study disease-related genes by shutting down the genes with virus-based techniques, including some that made use of the then-newly discovered mechanism of RNA interference.

In February 2011, US authorities filed criminal charges against Van Parijs in the US District Court in Boston, citing his use of fake data in a 2003 grant application to the National Insti-

\section{$\rightarrow$ NATURE.COM}

For a story involving whistleblowing, visit: go.nature.com/bxcnhn tutes of Health, based in Bethesda, Maryland. Van Parijs entered a guilty plea, and the government asked Judge Denise Casper for a 6-month jail term because of the seriousness of the fraud, which involved a \$2-million grant. "We want to discourage other researchers from engaging in similar behaviour," prosecutor Gregory Noonan, an assistant US attorney, told Nature.

On 13 June, Casper opted instead for six months of home detention with electronic monitoring, plus 400 hours of community service and a payment to MIT of $\$ 61,117$ - restitution for the already-spent grant money that MIT had to return to the National Institutes of Health. She cited assertions from the other scientists that Van Parijs was truly sorry. "I believe that the remorse that you've expressed to them, to the probation office, and certainly to the Court today, is heartfelt and deeply held, and I don't think it's in any way contrived for this Court," she said.

Among those pleading for clemency was David Baltimore, a Nobel prizewinner and former president of the California Institute of Technology, who had been both Van Parijs' postdoc supervisor and his co-author on two papers that had to be retracted because of fabrication. Baltimore told the court he never had any reason to doubt Van Parijs's veracity when he worked in his lab. In his letter, he said he believed that Van Parijs knew his actions were "antithetical to the principles of science" and that he had already suffered the greatest punishment a scientist can incur, the loss of his good name. Baltimore told Nature he felt a little compassion seemed in order. "I think the judge did a fair job of weighing the possible outcomes," he said.

Another clemency request came from Richard Hynes, an MIT biologist who was appointed as Van Parijs' advocate in the investigation there. Hynes argued that scientific whistleblowers might be reluctant to come forwards if they thought their allegations might result in jail for the accused.

But that is not how the whistleblowers in this case see it. One former member of Van Parijs' MIT lab, who spoke to Nature on condition of anonymity, says he doesn't think the prospect of Van Parijs' imprisonment would have deterred the group from coming forwards. Nor does he feel the punishment is adequate. "Luk's actions resulted in many wasted years as people struggled to regain their career paths. How do you measure the cost to the trainees when their careers have been derailed and their reputations brought into question?" he asks. The court did not ask these affected trainees for their statements before passing sentence on Van Parijs.

Van Parijs did not respond to a request for comment e-mailed to his attorneys or a voicemail left at a number listed for him in Falmouth, Massachusetts. The court filings state that after being fired by MIT, he got a job with a management consultancy firm, where his professionalism and integrity were highly rated. But he lost that job earlier this year after pleading guilty. The filings state that since that time his wife, also a scientist, has been the main breadwinner for their family of three young children. . 